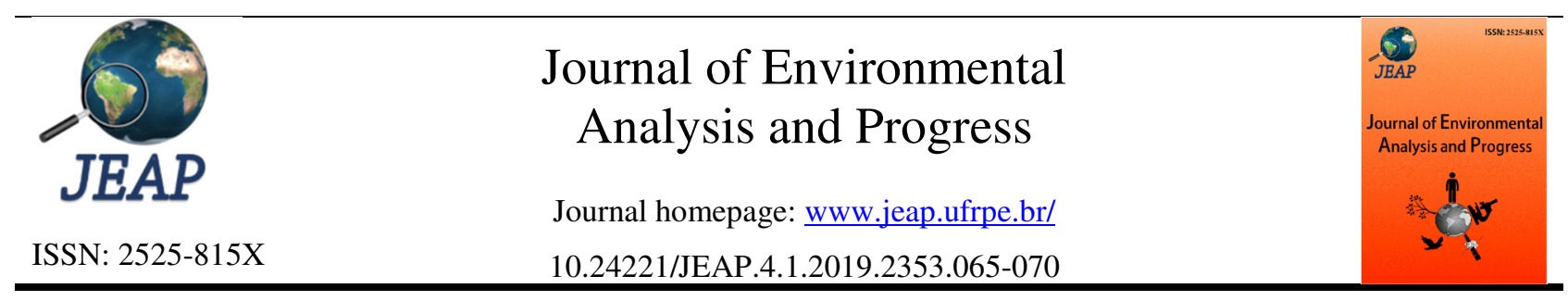

\title{
Socioeconomic aspects of the production chain of species Cardisoma guanhumi Latreille, 1828 in the Northeast coast of Brazil
}

\author{
Brunna de Andrade Lima Pontes Cavalcantia ${ }^{\mathrm{a}}$, Daywison Borges da Silva ${ }^{\mathrm{a}}$, Leandro Muniz Barbosa \\ da Silva ${ }^{a}$, Gilberto Gonçalves Rodrigues ${ }^{\mathrm{a}}$ \\ a Universidade Federal de Pernambuco-UFPE, Centro de Filosofia e Ciências Humanas-CFCH, Programa de Pós- \\ Graduação em Desenvolvimento e Meio Ambiente-PRODEMA. Rua Prof. Moraes Rego, n. 1235, $6^{\circ}$ andar, Sala 607, \\ Cidade Universitária, Recife-PE, Brasil. CEP: 50740-540. E-mail: brunnaandrade.ufpe@gmail.com, \\ daywisonborges@hotmail.com, muniz078@gmail.com, gilbertorodrigues.ufpe@gmail.com.
}

A R T I C L E I N F O

Received 18 Jan 2019

Accepted 30 Jan 2019

Published 31 Jan 2019

\begin{abstract}
A B S T R A C T
Mangroves are considered an important coastal ecosystem for feeding, protecting and breeding many species. Crustaceans constitute one of the most important groups of mangrove fauna, among the species traded in Brazil, Cardisoma guanhumi Latreille, 1828 (Guaiamum) stands out. In recent years, there has been a decline in the populations of $C$. guanhumi in Brazil and the species has come to be considered as critically endangered, remaining in this category until today. The species plays an important role in the local ecosystem, and social dynamics, the risk of extinction may lead to several negative social and environmental impacts. The research aimed to characterize the socioeconomic representation of this activity. The methodological procedures focused on bibliographical, documentary and cartographic review. For the identification of the flows linked to the production chains, the participant observation technique was used, accompanying the collectors in their work environments, the transport and commercialization transporters to the final destination. The results point to the identification of two flows (internal and external) that help to understand how the productive chain has been structured. The new modes of production have interfered in the social aspects of the productive chain of the species, being able to accentuate the situation of social vulnerability in which are inserted the social actors that depend on their harvesting. Therefore, it is necessary to create policies and instruments of governance for these territories that aim at planning, planning and environmental management for the regulation of the use of the species considering the aspects of local social dynamics.
\end{abstract}

Keywords: Conservation unit, mangrove, coastal zone, traditional communities.

\section{Introduction}

Mangroves provide adequate conditions for feeding, protection, and reproduction of many species is considered important transformers in the cycling of nutrients and organic matter (SchaefferNovelli, 1995). In addition to these relevant ecological characteristics, these ecosystems have socioeconomic importance, since they serve as sites for obtaining natural resources for many traditional communities, especially those related to fishing and hunting (Schaeffer-Novelli \& CintrónMolero, 1999).

Crabs are one of the most important groups of the mangrove fauna (Coelho et al., 2004), the crabs represent the main economic activity of the traditional human communities that inhabit the ecosystem above and among the species commercialized in Brazil, the guaiamum Cardisoma guanhumi (Latreille, 1828). Some characteristics of this fishing activity are of importance to the collectors, such as easy access to the mangrove, predictability, low cost of capture, good market acceptance and production autonomy (Nordson, 2004).

In recent years, there has been a decline in C. guanhumi populations in Brazil. In 2004, this species was included in the "Brazilian List of Aquatic Invertebrates and Fish on Exposed or Threatened" (MMA, 2004). Ten years later, the species was listed on the "National Official List of Threatened Species" as "Critically Endangered Species of Extinction, where it remains in this 
category. Interministerial Ordinance No. 38 of July 26,2018 , regulates the entire chain of production of guaiamum, and it is now prohibited to harvest, transport and commercialize, or to regulate activities only for the Sustainable Use Conservation Units, which presents a Plan of Management for the recovery of guaiamum and its entire production chain (Brazil, 2018).

Until then, laws were created and enforced without adjustment to local realities, and it was up to the collectors to obey them or not, at the risk of punishment. The consumer market of guaiamum is favorable to commerce, with the demand for its purchase being considered a spice in popular restaurants or even so-called "charme-restaurants". Scientific data on the growing exploitation of fishery resources are not yet known enough for northeastern Brazil, where there is intense demand for guaiamum. This situation affects more sharply the small fishermen, because these, in their great majority, coexist in difficult socioeconomic conditions and are less equipped of social possibilities to obtain alternatives for their subsistence. The concern with the sustainability of the fishery resources must, therefore, be attentive to the issue of ecosystem protection, but also with the social reproduction of the artisanal fisherman as a social and cultural individual (Lima \& Callou, 2015).

It is perceived that because of the ecosystemic characteristics, that interfere directly in the production, fishers and collectors are subject to such elements, and this reflects in an ordinary income marked by inconstancy. These conditions can be reverberated in the process of formation and consolidation of the productive chain, understanding that all transforming activity of nature is processed through work, which is the founding category of the relationship between society and nature, through which the human being transforms the natural environment, but also suffers the influences of it. Fishing is highly influenced by the forces of nature, with particular emphasis on the contiguous reflexes in the regularity of capture, in the constitution of surplus and the development of social relations linked to the production process (Diegues, 1983).

In this perspective, it is understood that the productive chain consists of a set of interactive components, inserting natural systems, productive systems, product suppliers, transport/distribution and marketing agents, as well as final consumers (Portugal, 1998). The productive chain is also influenced by the governmental structures responsible for regulation and supervision, which provide essential information for the sustainability of the activity.
An analysis of the concept of productive chain allows the understanding of exchanges constituted through the multiple elements that compose it. These processes establish interactions marked by complementarity and interdependence among the actors involved in their process. Thus, reflecting under this perspective makes it possible to clarify the relevance of each segment of the chain, as well as the fundamental understanding of production structures and the multiple relationships among its socioeconomic members (Knox \& Trigueiro, 2015).

This investigation considers the hypothesis that the practices of traditional traits, involved in the production chain of $C$. guanhumi in the Northeastern region of Brazil, are currently linked to the financial profit of its commercialization. So, the study aimed to characterize the socioeconomic representation of this activity.

\section{Material and Methods}

In order to reflect on the socioeconomic conditions of the guaiamum production chain, the present study had a spatial distribution of the object of study, the Acaú-Goiana Marine Extractive Reserve (Figure 1), which is inserted between the State of Paraíba and Pernambuco, in the municipalities of Caaporã-PB, Pitimbú-PB, and Goiana-PE. It was created in 2007 and has as managing body the Chico Mendes Institute for Biodiversity Conservation (ICMBio).

Considering the development of the reflections, it was tried to be based on theoretical principles of maximum comprehensiveness in which description, explanation, and understanding form the basis of totality, as well as the processes of interaction of the subject with the environment in which it is inserted, being considered jointly responsible for the transformations that occurred. The investigation was developed within a qualitative approach, since this type of research breaks with the epistemological parameters of the positivist paradigm, incorporating in its doing, the subject and its subjectivity. It appreciated the peculiar construction of everyday practices, which are seen not by their palpable, objectified, quantitative products, but by the significant process of their construction, which incorporates the representations, meanings and existential sense (Minayo, 2009).

The methodological procedures selected focused on bibliographical, documentary and cartographic review - collection of the material obtained and application of semi-structured interviews with the target audience of the research. For the identification of the flows linked to the production chains, the participant technique was 
used, accompanying the collectors in their working environments, the transporters responsible for transportation and marketing to the final destination. $\mathrm{n}$ the free fairs of Caxangá and Várzea, in Recife, traders and sellers of guaiamum were identified, who were asked about the resource, capture, and commercialization.

The project was approved through Protocol 92768418.0.0000.5208 by the UFPE Human Ethics Committee.
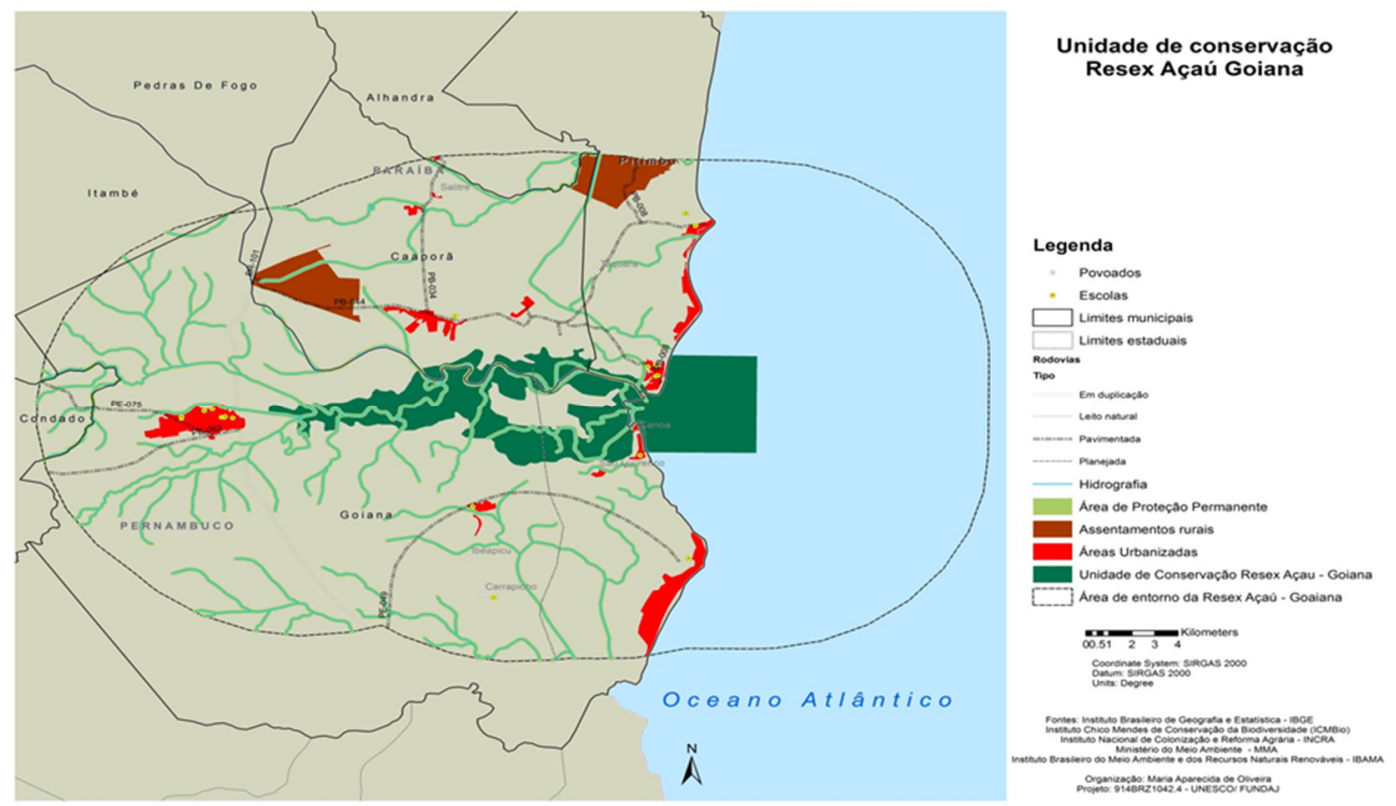

Figure I. Extractive Reserve (Resex) Acaú-Goiana (Thematic Map of the Conservation Unit and Environment Area). Font: Instituto Brasileiro de Geografia e Estatística (IBGE), Instituto Chico Mendes de Conservação da Biodiversidade (ICMBIO), Instituto Nacional de Colonização e Reforma Agrária (INCRA), Ministério do Meio Ambiente (MMA), Instituto Brasileiro do Meio Ambiente e dos Recursos Naturais Renováveis (IBAMA). Font: Adapted by Maria Gabriela Peixoto (2018).

\section{Results}

Considering that it is a resource that presents a complicated commercialization process due, in particular, to the lower demand for the buyers and the high price, when compared to crab-uçá, the number of collectors is remarkably reduced in the communities. The interviews were carried out with eleven people who have the source of income linked to guaiamum in the Acaú-Goiana RESEX, nine men and two women, all aged between 35 and 70 years. His work experiences with $C$. guanhumi range from 12 to 67 years, although some also work by cutting sugarcane. All respondents report that their parents were fishermen, but that they do not want their children to follow the same activity, preferring them to study. The residences are all in the Port of Congaçari, Caaporã, and Acaú, Pitimbu in Paraiba. All respondents agreed that the harvesting of guaiamum and other resources available in the mangrove and tide, such as fish, lobsters, siris, crabs, oysters, shellfish, were the primary source of income.

According to all the interviewees, there are two types of mangrove areas: the humid places, where they collect the caranguejo-uçá (Ucides cordatus Linnaeus, 1763), and the driest places, where they collect the guaiamum, the target of this study.

Cardisoma guanhumi constructs its galleries "burrows" in zones of "apicum", where the vegetation is distinct from the one found in the mangrove itself (Branco, 1990). They usually collect specimens from the Congaçari, Megaó and Goiana Port communities at RESEX.

In Acaú there is a trade in nurseries, bars, and local restaurants. Access to the collection points of guaiamum is performed by "bateras" (canoe), which are rowing or gasoline engine, some picking points can be made on foot. Exit times for specimen collection are structured based on tide schedules, always leaving at low tide time.

It was possible, based on the interviews, that the geographic distribution of activities related to guaiamum is currently structured in two circuits: the internal flows (Figure 2) and the external ones (Figure 3). 


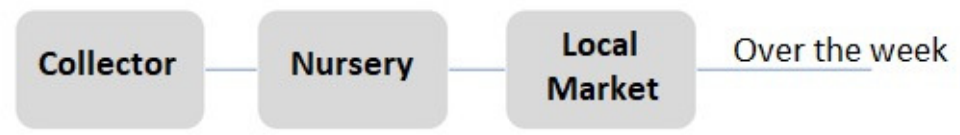

Figure 2. Internal Flow of the Cardisoma guanhumi Latreille, 1828 productive chain in the Acaú-Goiana RESEX. Brunna Cavalcanti (2019).

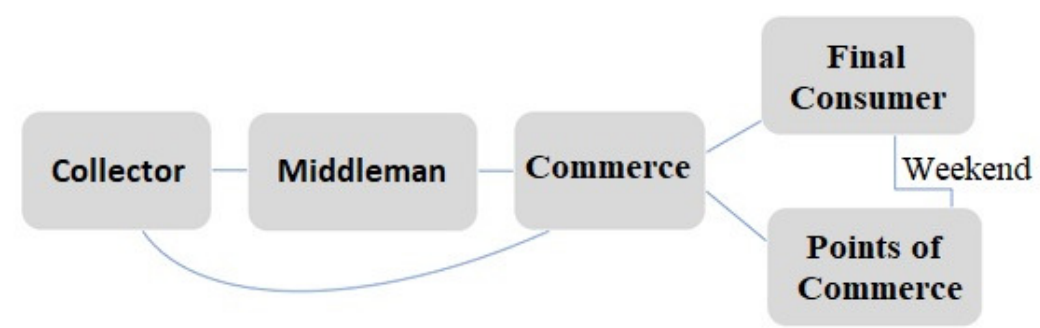

Figure III: External flow of the Cardisoma guanhumi Latreille, 1828 productive chain in the Acaú-Goiana RESEX. Brunna Cavalcanti (2019).

\section{Discussion}

The guaiamum productive chain in the spatial clipping object of study was consolidated. During the identification and characterization of its productive chain, it can be concluded that in the last stage of its cycle that is the distribution of the "product" there are two final destinations for species: the sale for commercialization in bars and restaurants or even directly to the consumer in your residence.

The collectors claimed to pick guaiamum from Monday to Friday, accentuating the days and times in the periods of greatest movement in the area (months referring to spring and summer). Considering the few collectors found in the AcaúGoiana RESEX, these affirmed that the sale of guaiamum would be a source of complementary income since the greater profitability comes from the commercialization of the Caranguejo-Uçá. The intermediaries, however, proved to be a bridge between the collectors and the commercial destinations. They are responsible for selling the product and supplying the stock at most of the outlets.

It is the middlemen, those responsible for acquiring the product directly from the collectors and promoting the transportation and distribution of the guaiamum in bars and restaurants, so it can be understood that these subjects play an important role in the production chain. It can be seen that bars form the most economical part of the productive chain, as well as the point of greater profitability tied to the economic actions of the species. Considering the inexistence of the demands from these commercial establishments would be financially viable, given that the demand of final consumers who choose to prepare the delicacy in their residences, ends up being low when compared to the consumption in bars and restaurants. Still, in the commercial establishments, the owners affirmed to look for the guaiamuns in the free fairs, where they make a connection with the middleman to whom they order the desired number of ropes.

The collectors are characterized as the social actor who moves to the areas where the species occurs and perform the capture of the animal with the trap called "mousetrap". The collectors themselves take the guaiamuns to a nursery for sale, where they later sell to residents, bars and restaurants in the region, buying and selling takes place throughout the week (Figure 2).

In the external flow (Figure 3), the collector can also be the subject that carries the material to a certain point of trade, or it transfers the collected Guaiamuns to a "broker" for later commercialization. In commerce, according to the informants, it occurs through direct sales to commercial establishments, such as bars, and restaurants or at strategic points, such squares and main avenues of the city of Recife, neighborhoods like Jaqueira, Casa Amarela, Espinheiro, Parnamirim, Casa Forte, IPSEP, Imbiribeira, Jordão, Várzea and in beaches, like Gaibú, in Cabo de Santo Agostinho, and other places near Caruaru, in the Agreste region of Pernambuco (Agrestina, Cupira).

These results and reflections, together with representatives of the RESCA Acau-Goiana, contribute to the understanding of the whole productive chain of Cardisoma guanhumi, where it is verified that there is an entire organization for this practice. We suggest that the research is replicated with a greater representation of interviewees to reach a greater number of actors involved in the guaiamum production chain in Northeast Brazil. It will bring contributions to the 
development of practices and processes in environmental governance that allow adequate management of the environmental resources present in the local coastal ecosystems. A more robust analysis of this activity intends to point out elements for the formulation and improvement of public policies for the exercise of participatory public environmental management of the fishery and use of the species in the state of Pernambuco, considering the aspects and social representation of the practice.

Considering the study of the flows of the production chain of Cardisoma Ganhumi in the State of Pernambuco, it was observed that the activity has been losing its traditional traits. It becomes a relevant activity that boosts the economic sector, having rebates even in the practice of the activity tourist. It shows that the practices, once considered as traditional, such as tipping and artisanal fishing, were passed on by individuals living in mangrove environments to their families and other members of the same community. It characterizes a form of socialization; the maintenance of the crop and subsistence ended up being converted into uniquely economic practices for income generation due to the growing demand for the species' consumption.

Considering that the traditional knowledge, previously used in the extraction and use of the environmental resources, in the mangrove environments for subsistence of the families, aimed to conserve these elements for the future generations. The monetarization of these and the subversion of the living being into a product are factors which not only endanger a species but a whole set of elements that are part of the same ecosystem. The characterization of the production chain can provide information on how best to benefit the class of fishermen, considering the species' carrying capacity and its sustainability.

\section{Conclusion}

Many families, such as residents of Resex Acaú-Goiana still make use of the mangrove's environmental resources, especially guaiamum for food and subsistence. The gradual destruction of the species also causes negative impacts on social aspects, since the harvest activity is still exercised with a strong traditional bias and guarantees the food security of these families. What is explicit is that the new modes of production have interfered in the social aspects of the productive chain of the species and can aggravate the situation of social vulnerability in which these individuals are inserted.

It is necessary to create policies and instruments of governance for these territories that aim at planning, planning and environmental management based on a perspective that includes the encouragement of the participation of the key actors, so that there are adequate conditions for the development of exploitation activities of the species, for economic purposes, in accordance with the local social dynamics and conservation of available environmental resources. This set of recommendations provides a contribution of sustainable practices for the organization of the human activities of using the environmental resources and avoid the existence of conflicts.

\section{Acknowledgments}

Authors are grateful to the communities of Resex Acaú-Goiana who participated in the research and shared their valuable knowledge; the group of the Management of Ecosystems of 2018.2 Programa de Pós-Graduação em Desenvolvimento e Meio Ambiente (PRODEMA) of the Universidade Federal de Pernambuco.

\section{References}

ALVES, R. R. N.; NISHIDA, A. K.; HERNÁNDEZ, M. I. M. 2005. Environmental perception of gatherers of the crab 'caranguejo-uçá' (Ucides cordatus, Decapoda, Brachyura) affecting their collection attitudes. Journal of Ethnobiology and Ethnomedicine, v. 1, n. 1, p. 10.

BRASIL. 2018. Portaria Interministerial $\mathrm{N}^{\circ} 38$, de 26 de julho de 2018. Define regras para o uso sustentável e para a recuperação dos estoques da espécie (Guaiamum, goiamú, caranguejo-azul, caraguejo-do-mato). Diário Oficial da União. Brasília, DF, ed. 144, p. 3.

BRANCO, J. O. 1990. Aspectos ecológicos de Brachyura (Crustáceos: Decapoda) no manguezal do Itacorubi, SC, Brasil. Revista Brasileira de Zoologia, v. 7, p. 165-179.

COELHO, P. A.; BATISTA-LEITE, L. M. A.; SANTOS, M. A. C.; TORRES, M. F. A. 2004. O manguezal. In: ESKINAZI-LEÇA, E.; NEUMANN-LEITÃO, S.; COSTA, M. F. Oceanografia: Um cenário tropical. Bagaço, Recife, Brasil, pp. 641-688.

DIEGUES, A. C. S. 1983. Pescadores, camponeses e trabalhadores do mar. Ed. Ática, SP, 279p.

FAO. 2015. Voluntary Guidelines for Securing Sustainable Small-Scale Fisheries. Food and Agriculture Organization of the United Nations. 34 p., Rome. 
GLASER, M.; DIELE, K. 2004. Asymmetric outcomes: assessing central aspects of the biological, economic and social sustainability of a mangrove crab fishery, Ucides cordatus (Ocypodidae), in North Brazil. Ecological Economics, v. 49, p. 361-373.

KNOX, W.; TRIGUEIRO, A. 2015. "Saberes, Narrativas e Conflitos na Pesca Artesanal", Vitoria, EDUFES. 229p.

LEITE, L. M. A. B. 2005. Estudo Etnocarcinológico do Cardisoma guanhumi Latreille, 1825 (Crustácea, Brachyura, Gecarcinidae) no Estuário do rio Goiana, Pernambuco, Brasil. Tese de Doutorado. Universidade Federal da Paraíba, 120p.

LIMA, A. C. C.; CALLOU, A. B. F. 2015. Políticas públicas e assistência técnica para pesca artesanal em Pernambuco. Contexto \& Educação, v. 30, n. 95, p. 93-116.

MANESCHY, M. C. 1993. Pescadores nos manguezais: estratégias técnicas e relações sociais de produção na captura de caranguejo. In: FURTADO, L. G.; LEITÃO, W.; MELLO, A. F. (Org.). Povos das águas: realidade e perspectiva na Amazônia. Belém: Museu Paraense Emílio Goeldi. pp. 19-62.

MMA. 2014. Ministério do Meio Ambiente. Lista Nacional Oficial de Espécies da Fauna Ameaçadas de Extinção-Peixes e Invertebrados Aquáticos. Portaria MMA no 445. Diário Oficial. Brasília, 18 de dezembro de 2014, No 245, Seção 1: p 110.
MINAYO, M.C.S. 2009. Pesquisa Social: teoria, método e criatividade. Petrópolis, RJ: Vozes, $28^{\mathrm{a}}$ edição.

NORDI, N. 1992. Os catadores de caranguejo-uçá (Ucides cordatus) da região de Várzea Nova (PB): uma abordagem ecológica e social. Tese de Doutorado. São Carlos: UFSCAR.

PORTUGAL, A. D. 1998. A importância estratégica da prospecção tecnológica para o SNPA. In: CASTRO, A. M. G.; LIMA, S. M. V.; GOEDERT, W. J.; FREITAS FILHO, A.; VASCONCELOS, J. R. P. Cadeias produtivas e sistemas naturais: Prospecção tecnológica. Brasília. Embrapa-SPI/ Embrapa-DPD. 564p.

SCHAEFFER-NOVELLI, Y. 1995. Manguezal Ecossistema entre a Terra e o Mar. São Paulo: Caribbean Ecological Research. 64p.

SCHAEFFER-NOVELLI, Y.; CINTRÓNMOLERO, G. 1999. Manguezal: Conservação e restauração, um conceito de manejo. VIII Congresso Latinoamericano sobre Ciências Del Mar, Trujillo, Peru.

SOARES, M. L. G. 1997. Estudo de biomassa aérea de manguezais do sudeste do Brasil - Análise de modelos. Tese Doutorado. Universidade de São Paulo, Instituto Oceanográfico.

OLIVEIRA, L. P. H. 1946. Estudos ecológicos dos crustáceos comestíveis uçá e guaiamú, Cardisoma guanhum Latreille e Ucides cordatu (L). Gecarcinidae, Brachyura. Memórias do Instituto Oswaldo Cruz, v. 44, p. 123-143. 